\title{
Weft, warp, and weave: the intricate tapestry of calcium channels regulating $\mathrm{T}$ Iymphocyte function
}

\author{
${ }^{1}$ Michael Smith Laboratories, University of British Columbia, Vancouver, BC, Canada \\ ${ }^{2}$ Centre for Blood Research, University of British Columbia, Vancouver, BC, Canada \\ ${ }^{3}$ The Brain Research Centre, University of British Columbia, Vancouver, BC, Canada \\ ${ }^{4}$ Department of Microbiology and Immunology, University of British Columbia, Vancouver, BC, Canada \\ ${ }^{5}$ Department of Medical Genetics, University of British Columbia, Vancouver, BC, Canada \\ ${ }^{6}$ Department of Zoology, University of British Columbia, Vancouver, BC, Canada
}

Kyla D. Omilusik ${ }^{1,2,3,4,5,6 \dagger}$, Lilian L. Nohara ${ }^{1,2,3,4,5,6}$, Shawna Stanwood ${ }^{1,2,3,4,5,6}$ and Wilfred A. Jefferies ${ }^{1,2,3,4,5,6 *}$

\section{Edited by:}

Gergely Toldi, Semmelweis

University, Hungary

Reviewed by:

Remy Bosselut, National Cancer Institute, USA

Jean Pieters, University of Basel,

Switzerland

*Correspondence:

Wilfred A. Jefferies, Michael Smith

Laboratories, University of British

Columbia, 301-2185 East Mall,

Vancouver, BC V6T 1Z4, Canada

e-mail:wilf@msl.ubc.ca

\section{${ }^{\dagger}$ Present address:}

Kyla D. Omilusik, Biological Sciences

Division, University of California San

Diego, La Jolla, CA, USA
Calcium $\left(\mathrm{Ca}^{2+}\right)$ is a universal second messenger important for $\mathrm{T}$ lymphocyte homeostasis, activation, proliferation, differentiation, and apoptosis. The events surrounding $\mathrm{Ca}^{2+}$ mobilization in lymphocytes are tightly regulated and involve the coordination of diverse ion channels, membrane receptors, and signaling molecules. A mechanism termed storeoperated $\mathrm{Ca}^{2+}$ entry (SOCE), causes depletion of endoplasmic reticulum (ER) $\mathrm{Ca}^{2+}$ stores following $T$ cell receptor (TCR) engagement and triggers a sustained influx of extracellular $\mathrm{Ca}^{2+}$ through $\mathrm{Ca}^{2+}$ release-activated $\mathrm{Ca}^{2+}(\mathrm{CRAC})$ channels in the plasma membrane. The $\mathrm{ER} \mathrm{Ca}{ }^{2+}$ sensing molecule, stromal interaction molecule 1 (STIM1), and a pore-forming plasma membrane protein, ORAl1, have been identified as important mediators of SOCE. Here, we review the role of several additional families of $\mathrm{Ca}^{2+}$ channels expressed on the plasma membrane of $\mathrm{T}$ cells that likely contribute to $\mathrm{Ca}^{2+}$ influx following TCR engagement, particularly highlighting an important role for voltage-dependent $\mathrm{Ca}^{2+}$ channels (Cav) in T lymphocyte biology.

Keywords: calcium, $\mathrm{T}$ cell, calcium channels, L-type calcium channels, $\mathrm{T}$ cell signaling
In the body's steady-state, a pool of T lymphocytes that express a diverse $\mathrm{T}$ cell receptor (TCR) repertoire is maintained in the periphery. In the event of an infection, $\mathrm{T}$ lymphocytes, through their TCR, recognize the infectious antigen and are activated and subsequently induced to proliferate and differentiate into effector cells capable of clearing the pathogen. Key components of the signaling events mediating $\mathrm{T}$ lymphocyte development, differentiation, homeostasis, effector function, and cell death are the universal second messenger calcium $\left(\mathrm{Ca}^{2+}\right)$ and the $\mathrm{Ca}^{2+}$ channels that regulate the intracellular $\mathrm{Ca}^{2+}$ levels (Smith-Garvin et al., 2009).

The activation of a $\mathrm{T}$ cell occurs when its TCR recognizes cognate antigen presented on major histocompatibility complex (MHC) by an antigen processing cell. In primary immune responses, this is the function of dendritic cell (DC). DCs take up soluble and particulate antigen as well as cellular debris by phagocytosis, endocytosis, or macropinocytosis and degrade them in endolysosomal compartments where liberated foreign antigens, usually peptides, are subsequently loaded onto MHC-I or MHC-II molecules that cycle to the plasma membrane. Here, the $\mathrm{MHC/foreign}$ antigen complex is recognized by a cognate TCR expressed on a specific T lymphocyte (Vyas et al., 2008). A series of signaling events ensue following ligation of the TCR. $\mathrm{Ca}^{2+}$ is critical to the TCR signaling processes. TCR engagement triggers an increase in intracellular $\mathrm{Ca}^{2+}$ levels resulting from the activation of phospholipase $\mathrm{C} \gamma 1$ (PLC $\gamma 1)$ and the associated hydrolysis of phosphatidylinositol-3,4-bisphosphate $\left(\mathrm{PIP}_{2}\right)$ into inositol-1,4,5-trisphosphate ( $\left.\mathrm{IP}_{3}\right)$ and diacylglycerol (DAG). $\mathrm{IP}_{3}$ binds to $\mathrm{IP}_{3}$ receptors $\left(\mathrm{IP}_{3} \mathrm{R}\right)$ in the endoplasmic reticulum (ER) causing release of $\mathrm{ER} \mathrm{Ca}^{2+}$ stores into the cytoplasm. During the event of store-operated $\mathrm{Ca}^{2+}$ entry (SOCE), depletion of $\mathrm{ER} \mathrm{Ca}^{2+}$ stores triggers a sustained influx of extracellular $\mathrm{Ca}^{2+}$ through $\mathrm{Ca}^{2+}$ release-activated $\mathrm{Ca}^{2+}(\mathrm{CRAC})$ channels in the plasma membrane (Hogan et al., 2010).

The sustained increase in intracellular $\mathrm{Ca}^{2+}$ results in the activation of signaling molecules and transcription factors that induce expression of genes required for $\mathrm{T}$ cell activation, proliferation, differentiation, and effector function. In $\mathrm{T}$ cells, $\mathrm{Ca}^{2+}$ can activate a variety of targets including the serine/threonine phosphatase calcineurin and its transcription factor target nuclear factor of activated $\mathrm{T}$ cells (NFAT), $\mathrm{Ca}^{2+}$-calmodulin-dependent kinase $(\mathrm{CaMK})$ and its target cyclic AMP-responsive elementbinding protein (CREB), myocyte enhancer factor 2 (MEF2) targeted by both calcineurin and CaMK, and nuclear factor kappa B (NFKB) (Oh-Hora, 2009). The best studied downstream effect of $\mathrm{Ca}^{2+}$ is the calcineurin-NFAT pathway. Increased $\mathrm{Ca}^{2+}$ levels promote the binding of $\mathrm{Ca}^{2+}$ to calmodulin inducing a conformational change that allows calmodulin to bind and activate calcineurin. Calcineurin dephosphorylates serines in the aminoterminus of NFAT exposing a nuclear localization signal. This results in the transport of NFAT into the nucleus, where NFAT can interact with other transcription factors, integrating signaling pathways, and inducing gene expression patterns dependent on the context of the TCR signaling (Hogan et al., 2003; Macian, 
2005; Smith-Garvin et al., 2009). $\mathrm{Ca}^{2+}$ has also been proposed to regulate the Ras/mitogen-activated protein kinase (MAPK) pathway in T cells. RasGRP that activates Ras not only has a DAG binding domain but also has a pair of EF-hand motifs that can directly bind $\mathrm{Ca}^{2+}$ (Cullen and Lockyer, 2002). Through this interaction, activation and membrane localization of Ras guanyl nucleotidereleasing protein (RasGRP) is influenced. Upon weak TCR stimulation, RasGRP localizes to the Golgi membrane whereas strong TCR signaling results in recruitment to the plasma membrane.
The site of activation may play a role in what extracellular-signalregulated kinase (ERK) can target downstream thereby contributing to differential signaling dependent on the stimulus (Teixeiro and Daniels, 2010).

There are several families of channels expressed on the plasma membrane of $\mathrm{T}$ lymphocytes (Kotturi et al., 2006) that may play important roles in $\mathrm{Ca}^{2+}$ entry (Figure 1). Recently, through genome wide high-throughput RNA interference screens and analysis of patients with severe combined immunodeficiency

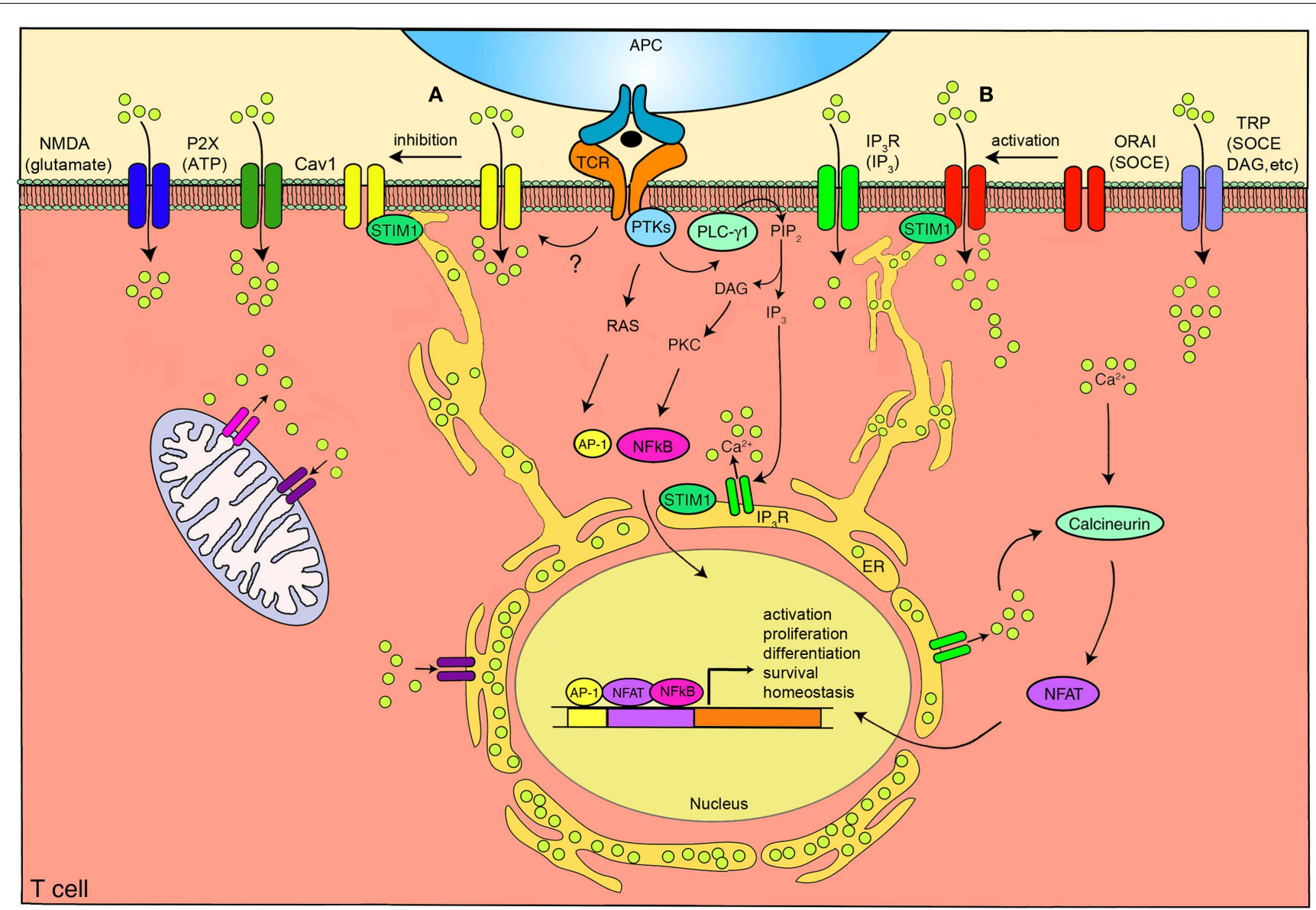

FIGURE 1 |The calcium channels in T cells. T cell receptor (TCR) engagement by a peptide-MHC on an antigen presenting cell (APC), induces protein tyrosine kinases (PTKs) to activate phospholipase C- $\gamma 1$ (PLC- $\gamma 1$ ), which cleaves phosphatidylinositol 4,5-bisphosphate $\left(\mathrm{PIP}_{2}\right)$ from plasma membrane phospholipids to generate diacylglycerol (DAG) and inositol-1,4,5-trisphosphate $\left(\mathrm{IP}_{3}\right)$. Elevated levels of $I \mathrm{P}_{3}$ in the cytosol leads

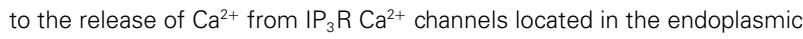
reticulum (ER). $\mathrm{Ca}^{2+}$ depletion from the $\mathrm{ER}$ induces $\mathrm{Ca}^{2+}$ influx from the extracellular space through the plasma membrane channel, ORAI1. Several auxiliary channels also operate during TCR-mediated $\mathrm{Ca}^{2+}$ signaling. These include plasma membrane $I P_{3} R$ activated by the ligand $I P_{3}$, transient receptor potential (TRP) channels that can be operated by DAG and store-operated $\mathrm{Ca}^{2+}$ entry (SOCE), adenosine triphosphate (ATP) responsive purinergic $\mathrm{P} 2(\mathrm{P} 2 \mathrm{X})$ receptors, glutamate mediated $N$-methyl-D-aspartate activated (NMDA) channels, and voltage-dependent $\mathrm{Ca}^{2+}$ channels $\left(\mathrm{Ca}_{\mathrm{v}} 1\right)$ that may be regulated through TCR signaling events. The mitochondria also control cytoplasmic $\mathrm{Ca}^{2+}$ levels. Increase in intracellular $\mathrm{Ca}^{2+}$ results in activation of calmodulin-calcineurin pathway that induces nuclear factor of activated T cells (NFAT) nuclear translocation and transcription of target genes to direct $\mathrm{T}$ cell homeostasis, activation, proliferation, differentiation, and survival. Within this complex network of $\mathrm{Ca}^{2+}$ signaling, a model of the reciprocal regulation of $\mathrm{Ca}_{\mathrm{v}} 1$ and ORAI1 in T cells has been proposed. (A) Low-level TCR signaling through interactions with self-antigens (i.e., self-peptides/self-MHC molecules) may result in $\mathrm{Ca}_{\mathrm{v}} 1$ (particularly $\mathrm{C} \mathrm{a}_{\mathrm{v}} 1.4$ ) activation and $\mathrm{Ca}^{2+}$ influx from outside the cell. This allows for filling of intracellular stores and initiation of a signaling cascade to activate a pro-survival program within the naïve T cell. Stromal interaction molecule 1 (STIM1) is not activated in this scenario and, consequently, ORAI1 remains closed. (B) Strong TCR signaling through engagement by a foreign peptide-MHC induces the downstream signaling events that result in $\mathrm{ER} \mathrm{Ca}^{2+}$ store depletion and STIM1 accumulation in puncta in regions of the ER near the plasma membrane allowing interactions with $\mathrm{Ca}^{2+}$ channels. ORAI1 enhances STIM1 recruitment to the vicinity of $\mathrm{Ca}_{\mathrm{v}} 1$ channels. Here, STIM1 can activate ORAI1 while inhibiting $\mathrm{Ca}_{\sqrt{V}}$ 1. PKC, protein kinase C. AP-1, activating protein-1. NFКB, nuclear factor kappa B. Yellow circles, $\mathrm{Ca}^{2+}$. 
(SCID), a pore-forming plasma membrane protein, ORAI1 (Feske et al., 2006; Vig et al., 2006; Zhang et al., 2006), and an ER $\mathrm{Ca}^{2+}$ sensing molecule, stromal interaction molecule 1 (STIM1) (Liou et al., 2005; Roos et al., 2005), have been identified as the classically defined CRAC channel. Transient receptor potential (TRP) channels have also been the focus of much attention and have been reported to be activated by store depletion in $\mathrm{T}$ cells. $\mathrm{IP}_{3}$ receptors $\left(\mathrm{IP}_{3} \mathrm{R}\right)$, similar to the ER-associated $\mathrm{Ca}^{2+}$ channels, have been shown to be expressed at the plasma membrane of $\mathrm{T}$ cells. In addition, $\mathrm{T}$ cell expressed adenosine triphosphate (ATP) responsive purinergic $\mathrm{P} 2(\mathrm{P} 2 \mathrm{X})$ receptors and glutamate mediated $\mathrm{N}$-methyl-D-aspartate (NMDA) activated receptors have shown significant $\mathrm{Ca}^{2+}$ permeability. Finally, voltage-dependent $\mathrm{Ca}^{2+}$ channels $\left(\mathrm{Cav}_{\mathrm{V}}\right)$, the focus of this review, have been identified to play a crucial function in T cells (Omilusik et al., 2011).

\section{ORAI AND STIM}

The discovery of the pore-forming plasma membrane proteins, ORAI1 and homologs ORAI2 and ORAI3, and the ER $\mathrm{Ca}^{2+}$ sensors, STIM1 and STIM2, has led to the development of a well-established paradigm of their coordinated action (Hogan et al., 2010; Feske et al., 2012; Srikanth and Gwack, 2012). TCR engagement triggers the generation of $\mathrm{IP}_{3}$ and the subsequent activation of $\mathrm{IP}_{3} \mathrm{Rs}$ that mediate the release of $\mathrm{Ca}^{2+}$ from the ER. The ER transmembrane protein, STIM1, can sense the depletion of $\mathrm{Ca}^{2+}$ stores. STIM1 exists as a monomer when $\mathrm{Ca}^{2+}$ is present, and its conformation is stabilized through an interaction between its luminal EF-hand domain and sterile $\alpha$-motif (SAM). When ER $\mathrm{Ca}^{2+}$ stores are depleted, the EF-SAM domain interaction in STIM1 becomes unstable resulting in the oligomerization of STIM1 molecules (Park et al., 2009; Stathopulos et al., 2009). STIM1 oligomers accumulate in puncta in regions of ER 10-25 nm beneath the plasma membrane (Liou et al., 2005, 2007; Wu et al., 2006a). Here, ORAI1 at the plasma membrane can interact with STIM1 (Luik et al., 2006; Xu et al., 2006). ORAI1 has been suggested to exist as a dimer in the plasma membrane and upon STIM1 interaction forms tetramers that can function to import $\mathrm{Ca}^{2+}$ (Penna et al., 2008).

Analyses of ORAI1 and STIM1 deficiency in human patients, that initially led to the identification of ORAI (Feske et al., 2006), as well as in mouse models, have validated their physiological role in $\mathrm{T}$ cell activation. In humans, loss of functional ORAI1 or STIM1 results in SCID (Partiseti et al., 1994; Le Deist et al., 1995; Feske et al., 2001, 2005, 2006; Picard et al., 2009). While lymphocyte numbers are normal in these patients, impaired SOCE leaves $\mathrm{T}$ cells with diminished ability to proliferate and produce cytokines upon activation. Analogous phenotypes are observed in animal models. In ORAI1 ${ }^{-1-}$ and STIM1 ${ }^{-1-}$ mice, thymic development of conventional TCR $\alpha \beta$ T cells appears normal. However, impaired selection of agonist-selected $\mathrm{T}$ cells, $\mathrm{T}$ regulatory cells $\left(\mathrm{T}_{\text {reg }}\right)$, invariant natural killer T cells and TCR $\alpha \beta^{+} \mathrm{CD} 8 \alpha \alpha^{+}$ intestinal intraepithelial lymphocytes, owing to a defect in IL-2 or IL-15 signaling has been noted in STIM1- and STIM2-deficient mice (Oh-Hora et al., 2013). ORAI1-deficiency causes a moderate reduction in SOCE and subsequent cytokine production in T cells (Gwack et al., 2008; Vig et al., 2008). STIM1-deficient T cells have no CRAC channel function or SOCE, no subsequent activation of
NFAT transcription factor and, as a result, have impaired cytokine secretion (Oh-Hora et al., 2008). This impacts T cell responses and, consequently, confers protection from experimental autoimmune encephalomyelitis (EAE) due to poor generation of $\mathrm{Th}_{1} / \mathrm{Th}_{17}$ responses (Schuhmann et al., 2010).

Interestingly, STIM-deficiency is also associated with lymphoproliferative and autoimmune diseases. In SCID patients, this is seen as lymphadenopathy (enlarged lymph nodes) and hepatosplenomegaly (enlarged liver and spleen) as well as autoimmune hemolytic anemia and thrombocytopenia resulting from immune responses directed against the red blood cells and platelets, respectively (Picard et al., 2009). It has been suggested that this autoimmunity observed in STIM1-deficient patients is a consequence of the reduced $\mathrm{T}_{\text {reg }}$ cell numbers found in the periphery (Feske, 2009; Picard et al., 2009). Similarly, mice lacking both STIM1 and STIM2 experienced autoimmune and lymphomyeloproliferative syndromes again due to a severe reduction in $T_{\text {reg }}$ number in the thymus and secondary lymphoid organs and impaired $\mathrm{T}_{\text {reg }}$ suppressive function (Oh-Hora et al., 2008). This $\mathrm{T}_{\text {reg }}$ deficiency is presumably a result of poor $\mathrm{Ca}^{2+} / \mathrm{NFAT}-$ dependent induction of Foxp3 expression (Wu et al., 2006b; Oh-Hora et al., 2008; Tone et al., 2008). Together, these studies highlight the importance of ORAI1/STIM1 in T cell activation and immune tolerance.

T cells also express family members ORAI2 and ORAI3 that exhibit similar structure to ORAI1. ORAI2 and ORAI3 form $\mathrm{Ca}^{2+}$-permeable ion pores; however, these channels differ in their pharmacology, ion selectivity, activation kinetics, and inactivation properties in comparison to ORAI1 (Lis et al., 2007). Overexpression of ORAI2 or ORAI3 with STIM1 can result in $\mathrm{Ca}^{2+}$ currents similar but not identical to the CRAC current (DeHaven et al., 2007; Lis et al., 2007). However, ORAI2's contribution to $\mathrm{Ca}^{2+}$ signaling in differentiated $\mathrm{T}$ cells is questionable as overexpression of ORAI2 in ORAI1 ${ }^{-l-}$ T cells does not restore SOCE (Gwack et al., 2008). ORAI2 expression is high in naïve T cells and is down regulated upon activation; therefore, ORAI2 may have a major role in development or peripheral homeostasis (Gwack et al., 2008; Vig et al., 2008). ORAI3 has been shown to form pentamers with ORAI1 to make up the arachidonate-regulated $\mathrm{Ca}^{2+}$-selective (ARC) channels (Mignen et al., 2009). These channels are activated by arachidonic acid rather than store-depletion and require plasma membrane localized STIM1 for their regulation (Mignen et al., 2007). Their role in T cells has yet to be determined.

STIM2 with $42 \%$ sequence similarity to STIM1 is also found in T cells. While STIM1 has relatively high and constant expression and can be found to some extent in the plasma membrane as well as the ER, STIM2 is expressed at low levels in naïve T cells but is upregulated upon TCR activation and is exclusively localized to the ER (Williams et al., 2001; Soboloff et al., 2006). Like STIM1, STIM2 functions as an $\mathrm{ER} \mathrm{Ca}^{2+}$ sensor and is able to mediate SOCE in lymphocytes. Nevertheless, STIM2 does not seem to serve a redundant purpose as its overexpression only partially rescues $\mathrm{Ca}^{2+}$ influx deficiency in STIM1 ${ }^{-1-} \mathrm{T}$ cells (Brandman et al., 2007; Oh-Hora et al., 2008). Upon $\mathrm{Ca}^{2+}$ store depletion, STIM2 also oligomerizes and localizes to puncta at ER-plasma membrane contacts; however, STIM2 detects smaller decreases in 
$\mathrm{ER} \mathrm{Ca}^{2+}$ concentration and forms multimers with slower kinetics than STIM1 with some STIM2 already activated in resting cells with replete $\mathrm{Ca}^{2+}$ stores (Soboloff et al., 2006; Brandman et al., 2007). This fits with the established role for STIM2 in regulating basal $\mathrm{Ca}^{2+}$ influx and stabilizing cytosolic and $\mathrm{ER} \mathrm{Ca}^{2+}$ levels in resting cells (Brandman et al., 2007). It also explains the fact that STIM2-deficiency has minimal effect on the initial $\mathrm{Ca}^{2+}$ entry but impairs the ability of $\mathrm{T}$ cells to maintain nuclear translocation of NFAT and cytokine production (Oh-Hora et al., 2008). Where STIM1 readily senses $\mathrm{ER} \mathrm{Ca}^{2+}$ store depletion and can initiate SOCE, STIM2 remains active in higher $\mathrm{Ca}^{2+}$ levels when stores are refilling and can sustain the response (Oh-Hora, 2009).

Although the details of the ORAI-STIM pathway have been the subject of a large amount of recent work, this scheme does not account for the involvement of other currents mediated by additional plasma membrane $\mathrm{Ca}^{2+}$ channels that have been shown to be expressed and function in T cells (Kotturi et al., 2003; Kotturi and Jefferies, 2005; Omilusik et al., 2011), nor does it allow for differential patterns in $\mathrm{Ca}^{2+}$ response between $\mathrm{T}$ cell subsets (Fanger et al., 2000; Weber et al., 2008; Robert et al., 2011). Immunologists are only beginning to acknowledge, accept, and integrate these channels into the pantheon of functions mediated by $\mathrm{T}$ cells. Therefore, incorporating multiple $\mathrm{Ca}^{2+}$ channels into a comprehensive model is essential for the complete understanding of $\mathrm{Ca}^{2+}$ signaling in T cells.

\section{IMPORTANT ADDITIONAL $\mathrm{Ca}^{2+}$ CHANNELS IN T LYMPHOCYTES \\ IP $_{\mathbf{3}}$ RECEPTORS}

The $\mathrm{IP}_{3} \mathrm{Rs}$, similar to those found in the ER, have been suggested to function as $\mathrm{Ca}^{2+}$ channels at the plasma membrane (Khan et al., 1992; Kotturi et al., 2006). IP 3 dissipates rapidly after TCR engagement; therefore, $\mathrm{IP}_{3}$ induced activation of plasma membrane receptors would only contribute to short-term $\mathrm{Ca}^{2+}$ signaling (Kotturi et al., 2006). Alternatively, it was suggested that $\mathrm{IP}_{3} \mathrm{Rs}$ in the ER, known to bind $\mathrm{IP}_{3}$ to deplete ER $\mathrm{Ca}^{2+}$ stores, change conformation upon ER store depletion, and signal to surface $\mathrm{IP}_{3} \mathrm{Rs}$ to open (Berridge, 1993). $\mathrm{IP}_{3} \mathrm{Rs}$ have been identified on the cell surface of cultured T cells (Khan et al., 1992; Tanimura et al., 2000). However, $\mathrm{IP}_{3}$-induced $\mathrm{Ca}^{2+}$ currents across the plasma membrane could not be detected (Zweifach and Lewis, 1993). As an alternate function based on the numerous protein binding sites present in the modulatory domain of the channel, $\mathrm{IP}_{3} \mathrm{Rs}$ have been proposed to operate at the plasma membrane as scaffolds (Patterson et al., 2004). Further work is required to clearly fit the $\mathrm{IP}_{3} \mathrm{R}$ into the $\mathrm{Ca}^{2+}$ signaling network in $\mathrm{T}$ cells.

\section{TRANSIENT RECEPTOR POTENTIAL CHANNELS}

The first TRP family member was discovered in Drosophila and was found to have a role in visual transduction (Montell and Rubin, 1989). Subsequently, 28 mammalian TRP channel proteins have been identified. These are grouped into six subfamilies based on amino acid sequence similarities: the classical TRPs (TRPCs) that are most similar to Drosophila TRP; the vanilloid receptor TRPs (TRPVs); the melastatin TRPs (TRPMs); the mucolipins (TRPMLs); the polycystins (TRPPs); and ankyrin transmembrane protein 1 (TRPA1) (Clapham et al., 2003; Montell and Rubin, 1989). The six transmembrane domain TRP channels form pores that are permeable to cations including $\mathrm{Ca}^{2+}$ (Owsianik et al., 2006). Various TRP channel family members have been shown to be expressed in cultured or primary T cells (Schwarz et al., 2007; Oh-Hora, 2009; Wenning et al., 2011).

Before the discovery of ORAI1 and STIM1, TRP channels were investigated as candidates for the CRAC channel. The TRPV6 channel is highly permeable to $\mathrm{Ca}^{2+}$ and has been shown to be activated by store-depletion (Cui et al., 2002). In addition, when a dominant-negative pore-region mutant of TRPV6 was expressed in Jurkat T cells, the CRAC current was diminished (Cui et al., 2002). However, in subsequent studies, the CRAC channel inhibitor, BTP2, had no effect on TRPV6 channel activity (Zitt et al., 2004; He et al., 2005; Schwarz et al., 2006) and the role of TRPV6 as a CRAC channel could not be confirmed (Voets et al., 2001; Bodding et al., 2002). TRPC3 channels were also under consideration as CRAC channels following the discovery that Jurkat $\mathrm{T}$ cell lines with mutated TRPC3 channels had reduced $\mathrm{Ca}^{2+}$ influx following TCR stimulation. This impairment could be overcome by overexpression of a wild-type TRPC3 (Fanger et al., 1995; Philipp et al., 2003). Furthermore, siRNA knockdown of TRPC3 expression in human T cells resulted in reduced proliferation following TCR stimulation (Wenning et al., 2011). However, while TRPC3 has been shown to be activated in response to storedepletion (Vazquez et al., 2001), the major stimulus gating TRPC3 seems to be DAG (Hofmann et al., 1999).

Although not store-operated, the TRPM2 channel in T cells has also been examined. TRMP2 is a non-selective $\mathrm{Ca}^{2+}$ channel that is activated by the intracellular secondary messengers ADP-ribose (ADPR), nicotinamide adenine dinucleotide $\left(\mathrm{NAD}^{+}\right)$, hydrogen peroxide $\left(\mathrm{H}_{2} \mathrm{O}_{2}\right)$, and cyclic ADPR (Perraud et al., 2001; Hara et al., 2002; Massullo et al., 2006). It has been proposed that activation of $\mathrm{T}$ cells can increase endogenous ADPR levels in $\mathrm{T}$ cells which results in $\mathrm{Ca}^{2+}$ entry through TRPM2 and subsequent induction of cell death demonstrating that TRPM2 can contribute to some degree to $\mathrm{Ca}^{2+}$ signaling in T cells (Gasser et al., 2006). Recently, the TRPM2 channels have been implicated in $\mathrm{T}$ cell effector function. CD4 ${ }^{+} \mathrm{T}$ cells from TRPM2-deficient mice were shown to have reduced ability to proliferate and secrete cytokines following TCR activation. Furthermore, TRPM2-deficient mice had decreased inflammation and demyelinating spinal cord lesions in an EAE model (Melzer et al., 2012). Although important to T cell function, the current role of TRP receptors in $\mathrm{Ca}^{2+}$ signaling is still under investigation.

\section{ATP-RESPONSIVE PURINERGIC P2 RECEPTORS (P2X)}

The $\mathrm{P} 2 \mathrm{X}$ receptors are ATP-gated ion channels that permit the influx of extracellular cations including $\mathrm{Ca}^{2+}$ ions (reviewed in Junger, 2011). Four family members in particular, P2X1, P2X2, $\mathrm{P} 2 \mathrm{X} 4$, and P2X7, have been associated with T cells and may serve to amplify the TCR signal to ensure antigen recognition and T cell activation through an autocrine feedback mechanism (Bours et al., 2006; Yip et al., 2009; Woehrle et al., 2010; Junger, 2011). Upon TCR engagement, ATP is released through Pannexin 1 hemichannels that localize to the immunological synapse where they release ATP that acts on the P2X channels to promote $\mathrm{Ca}^{2+}$ influx and 
enhance signaling (Filippini et al., 1990; Schenk et al., 2008; Yip et al., 2009). In particular, P2X1, 4, and 7 have been shown to contribute to the increase in intracellular $\mathrm{Ca}^{2+}$, NFAT activation, proliferation, and IL-2 production in murine and human T cells following stimulation (Baricordi et al., 1996; Schenk et al., 2008; Yip et al., 2009; Woehrle et al., 2010). Initial analysis of P2X7 receptor-deficient mice revealed no major defects in T cell development (Solle et al., 2001). However, additional studies did identify a deficiency in $\mathrm{T}_{\text {reg }}$ stability and function as well as $\mathrm{Th}_{17}$ differentiation (Schenk et al., 2011). Also, T cells from C57Bl/6 mice with a natural mutation in the P2X7 gene that reduces ATP sensitivity have been shown to produce reduced amounts of IL-2 following stimulation compared to Balb/c mice with a fully functional receptor further delineating a role for P2X receptors in $\mathrm{T}$ cell function (Adriouch et al., 2002; Yip et al., 2009). Likewise, in two models of $\mathrm{T}$ cell-dependent inflammation, treatment with a P2XR antagonist impeded the development of colitogenic $\mathrm{T}$ cells in inflammatory bowel disease and induced unresponsiveness in anti-islet TCR transgenic T cells in diabetes (Schenk et al., 2008). Therefore, it is clear that P2X channels are playing an important role in $\mathrm{T}$ cell $\mathrm{Ca}^{2+}$ signaling; however, the specific mechanistic details of how they fit into shaping the $\mathrm{T}$ cell $\mathrm{Ca}^{2+}$ environment need further exploration.

\section{$\boldsymbol{N}$-METHYL-D-ASPARTATE ACTIVATED RECEPTORS}

The NMDA receptors are a class of ligand-gated glutamate ionotropic receptors found in the central nervous system that play a crucial role in neuronal function. These receptors are heterotetramers composed of two subunits, NR1 and NR2, that form an ion channel which is highly permeable to $\mathrm{K}^{+}, \mathrm{Na}^{+}$, and $\mathrm{Ca}^{2+}$ (Boldyrev et al., 2012). $\mathrm{Ca}^{2+}$ entry through the receptors into the cell occurs when the NMDA receptors are activated by binding to their ligands, glutamate and glycine. In neurons, this allows for long-lasting memory formation (Boldyrev et al., 2012). Interestingly, NMDA receptors have been shown to be expressed on rodent and human $\mathrm{T}$ cells and contribute to the increase in intracellular $\mathrm{Ca}^{2+}$ level following $\mathrm{T}$ cell activation (Lombardi et al., 2001; Boldyrev et al., 2004; Miglio et al., 2005, 2007; Mashkina et al., 2007, 2010). Zainullina et al. (2011) further demonstrated that activation of $\mathrm{T}$ cells with thapsigargin, an inhibitor of a $\mathrm{Ca}^{2+}$-ATPase of the ER that induces $\mathrm{Ca}^{2+}$ store depletion and activation of plasma membrane $\mathrm{Ca}^{2+}$ channels, in the presence of an NMDA receptor antagonist did not affect the movement of $\mathrm{Ca}^{2+}$ from intracellular stores. However, it reduced the influx of $\mathrm{Ca}^{2+}$ from the extracellular space suggesting that NMDA receptors participate in SOCE, at least to some degree. In this scenario, the NMDA receptors may be mainly contributing to Ras/Rac-dependent signaling in $\mathrm{T}$ cells following TCR engagement (Zainullina et al., 2011). Analogous to neuronal synapses, a recent study of thymocytes showed that upon TCR stimulation, NMDA receptors localize to the immunological synapse (Affaticati et al., 2011). Here, DCs rapidly release glutamate that activates the NMDA receptors on the T cells contributing to the increase in intracellular $\mathrm{Ca}^{2+}$ concentration. It is suggested that glutamate signaling through these receptors may participate in negative selection in the thymus by inducing apoptosis in thymocytes while it may influence proliferation in peripheral $\mathrm{T}$ cells (Affaticati et al., 2011). Further studies are required to determine the role glutamate plays in shaping the $\mathrm{Ca}^{2+}$ signal in T cells.

\section{VOLTAGE-DEPENDENT $\mathrm{Ca}^{2+}$ CHANNELS}

$\mathrm{Ca}_{V}$ channels function typically in excitable cells such as nerve, muscle, and endocrine cells where they open in response to membrane depolarization to allow $\mathrm{Ca}^{2+}$ entry (Buraei and Yang, 2010). The $\mathrm{Cav}_{\mathrm{V}}$ channels were initially classified based on the voltage required for activation into the subgroups high-voltage activated (HVA) and low-voltage activated (LVA) channels. Further analysis of the $\mathrm{Ca}_{V}$ channels allowed for additional classification of the channels into groups with distinct biophysical and pharmacological properties: $\mathrm{T}$ (tiny/transient)-, $\mathrm{N}$ (neuronal)-, $\mathrm{P} / \mathrm{Q}$ (Purkinje)-, R (toxin-resistant)-, L (long-lasting)-type channels (Lacinova, 2005; Buraei and Yang, 2010).

The $\mathrm{Ca}_{\mathrm{V}}$ channels are heteromultimeric protein complexes composed of five subunits: $\alpha_{1}, \alpha_{2}, \beta, \delta$, and $\gamma$. The $\alpha_{2}$ and $\delta$ subunits are linked together through disulfide bonds to form a single unit referred to as $\alpha_{2} \delta$. The $\alpha_{1}$ subunit of the channel is the pore-forming component responsible for the channel's unique properties while the $\alpha_{2} \delta, \beta$, and $\gamma$ subunits regulate the structure and activity of $\alpha_{1}$ (Buraei and Yang, 2010). The $\alpha_{1}$ subunit consists of four homologous repeated motifs (I-IV) each composed of six transmembrane segments (S1-S6) with a re-entrant poreforming loop (P-loop) between S5 and S6. The P-loop contains four highly conserved negatively charged amino acids responsible for selecting and conducting $\mathrm{Ca}^{2+}$ while the $\mathrm{S} 6$ segments form the inner pore (Buraei and Yang, 2010). The S4 segments are positively charged and constitute the voltage sensor. The pore opens and closes through voltage-mediated movement of this sensor (Lacinova, 2005).

Ten mammalian $\alpha_{1}$ subunits are divided into three subfamilies based on similarities in amino acid sequence. The Cav 1 family contains L-type channels; the Cav 2 family consists of N-, P/Q-, and R-type channels; and the $\mathrm{Ca}_{V} 3$ family are T-type channels (Buraei and Yang, 2010). Initially, "voltage-operable" current seemingly activated by TCR engagement or store depletion with electrophysiological properties different than the CRAC current in the plasma membrane of Jurkat T cells was identified (Densmore et al., 1992, 1996). Subsequently, numerous pharmacological and genetic studies have demonstrated the existence of Cav 1 or L-type channels in T cells (Table 1). The Cav 1 channels exist as four isoforms: Cav 1.1, $\mathrm{Ca}_{V}$ 1.2, Cav 1.3, and Cav 1.4. In excitable cells, L-type $\mathrm{Ca}^{2+}$ channels require high-voltage activation and have slow current decay kinetics. They have a unique sensitivity to 1,4-dihydropyridines (DHPs), a wide drug class that can either activate (for example: Bay K 8644) or inhibit (for example: nifedipine) the activity of the channel (Lacinova, 2005).

Early studies suggesting that L-type $\mathrm{Ca}^{2+}$ channels contributed to $\mathrm{T}$ cell $\mathrm{Ca}^{2+}$ signaling relied on pharmaceutical analysis (Grafton and Thwaite, 2001; Kotturi et al., 2003; Gomes et al., 2004). These include in vitro experiments where the DHP antagonist nifedipine was shown to block proliferation of human $\mathrm{T}$ cells or peripheral blood mononuclear cells or impair increase in intracellular $\mathrm{Ca}^{2+}$ following stimulation with mitogens (Birx et al., 1984; Gelfand et al., 1986; Dupuis et al., 1993). This effect of nifedipine seemed to be dose-dependent when $\mathrm{T}$ cells were stimulated 
Table 1 | Cav $1 \mathrm{Ca}^{2+}$ channel expression in $\mathrm{T}$ cells.

\begin{tabular}{|c|c|c|c|}
\hline Subtype & Distribution & Analysis & Reference \\
\hline \multirow[t]{3}{*}{ Cav 1.1} & Mouse CTLs & Protein & Matza et al. (2009) \\
\hline & Mouse effector $\mathrm{CD}^{+} \mathrm{T}$ cells & mRNA (PCR); protein & Jha et al. (2009) \\
\hline & Mouse CD4+ $T$ cells & mRNA (PCR); protein & Badou et al. (2006), Matza et al. (2008) \\
\hline \multirow[t]{6}{*}{ Cav 1.2} & $\begin{array}{l}\text { Human peripheral blood T cells; human Jurkat, } \\
\text { MOLT-4, CEM T cell lines }\end{array}$ & $\begin{array}{l}\text { mRNA (partial sequence); protein } \\
\text { (truncated/full) }\end{array}$ & Stokes et al. (2004) \\
\hline & Mouse CTLs & Protein & Matza et al. (2009) \\
\hline & Mouse $\mathrm{CD}^{+}{ }^{+} \mathrm{T}$ cells & mRNA (PCR) & Jha et al. (2009) \\
\hline & Mouse CD4 ${ }^{+} \mathrm{T}$ cells & mRNA (PCR); protein & Badou et al. (2006), Matza et al. (2008) \\
\hline & Mouse CD4+ Th2 cells & mRNA (sequence); protein & Cabral et al. (2010) \\
\hline & Mouse BDC2.5 CD4 ${ }^{+} \mathrm{T}$ cells & mRNA (PCR) & Lee et al. (2008) \\
\hline \multirow[t]{4}{*}{ Cav 1.3} & Human Jurkat T cell line & mRNA (partial sequence); protein (truncated) & Stokes et al. (2004) \\
\hline & & mRNA (PCR) & Colucci et al. (2009) \\
\hline & Mouse $\mathrm{CD}^{+}{ }^{+}$T cells & mRNA (PCR) & Jha et al. (2009) \\
\hline & Mouse CD4+ Th2 cells & mRNA (sequence); protein & Cabral et al. (2010) \\
\hline \multirow[t]{5}{*}{ Cav 1.4} & $\begin{array}{l}\text { Human Jurkat T cell line; human spleen; human } \\
\text { peripheral blood } \mathrm{CD} 4^{+} / \mathrm{CD}^{+} \mathrm{T} \text { cells }\end{array}$ & mRNA (sequence); protein & $\begin{array}{l}\text { Kotturi et al. (2003), Kotturi and Jefferies } \\
\text { (2005) }\end{array}$ \\
\hline & Human spleen and thymus; rat spleen and thymus & mRNA (PCR); protein & McRory et al. (2004) \\
\hline & Mouse T cells & mRNA (PCR); protein (truncated) & Omilusik et al. (2011) \\
\hline & Mouse naïve $\mathrm{CD}^{+} \mathrm{T}$ cells & mRNA (PCR); protein & Jha et al. (2009) \\
\hline & Mouse $\mathrm{CD} 4^{+} \mathrm{T}$ cells & mRNA (PCR) & Badou et al. (2006), Colucci et al. (2009) \\
\hline
\end{tabular}

in the presence of the immunosuppressive agent cyclosporine A (Marx et al., 1990; Padberg et al., 1990). In a resultant study performed by Kotturi et al. (2003), treatment of Jurkat T cells and human peripheral blood T cells with the DHP agonist Bay K 8644 was shown to increase intracellular $\mathrm{Ca}^{2+}$ levels and induce ERK $1 / 2$ phosphorylation, while treatment with the DHP antagonist nifedipine blocked $\mathrm{Ca}^{2+}$ influx, ERK $1 / 2$ phosphorylation, NFAT activation, IL-2 production, and $\mathrm{T}$ cell proliferation. At micromolar concentrations, DHPs can also affect the function of $\mathrm{K}^{+}$ channels and therefore conclusions drawn from these pharmaceutical studies (Grafton and Thwaite, 2001; Kotturi et al., 2003, 2006; Gomes et al., 2004) regarding contribution of Cav 1 to T cell function have been criticized (Wulff et al., 2003, 2004). However, inhibitory effects have been noted when DHP antagonists were used at concentrations well below those influencing $\mathrm{K}^{+}$channels (Sadighi Akha et al., 1996; Kotturi et al., 2003) as well as with the more specific $\mathrm{Ca}_{V} 1$ blocker, calciseptine, that also obstructs $\mathrm{Ca}^{2+}$ influx in T cells (de Weille et al., 1991; Matza and Flavell, 2009).

Subsequent genetic studies have confirmed the expression of L-type $\mathrm{Ca}^{2+}$ channels in $\mathrm{T}$ cells and have gone on to compare their structure to those found in excitable cells. $\mathrm{Ca}_{\mathrm{V}} 1.4$ was the first $\mathrm{Ca}_{V} 1$ channel identified in T cells (Kotturi et al., 2003; Kotturi and Jefferies, 2005; Omilusik et al., 2011). The Cav1.4 $\alpha_{1}$ subunit is encoded by the CACNA1F gene originally cloned from human retina (Fisher et al., 1997) where Cav1.4 mediates $\mathrm{Ca}^{2+}$ entry into the photoreceptors promoting tonic neurotransmitter release (Strom et al., 1998). Kotturi et al. identified the Cav $1.4 \alpha_{1}$ subunit mRNA and protein in Jurkat $\mathrm{T}$ cells as well as in human peripheral blood T cells (Kotturi et al., 2003; Kotturi and Jefferies, 2005). This human lymphocyte form of Cav1.4 was shown to undergo alternative splicing, resulting in a protein smaller in size compared to a retinoblastoma version (Kotturi and Jefferies, 2005). Sequence analysis revealed that the Cav1.4 expressed in human $\mathrm{T}$ cells exists as two novel splice variants (termed Cav1.4a and Cav1.4b) distinct from the retina (Kotturi and Jefferies, 2005). Cav 1.4a lacks exons 31, 32, 33, 34, and 37 resulting in deletions of transmembrane segments S3, S4, S5, and half of S6 in motif IV. As a result, the voltage sensor domain and part of the DHP binding site and EF-hand $\mathrm{Ca}^{2+}$ binding motif are deleted from the channel. While the removal of the voltage sensor may alter the voltage-gated activation of this channel, partial deletion of the DHP binding site may decrease the sensitivity of $\mathrm{T}$ cell-specific Cav1.4 channels. This explained why large doses of DHP antagonists are required to completely block $\mathrm{Ca}^{2+}$ influx through Cav channels in T cells (Dupuis et al., 1993). Remarkably, the splice event caused a frameshift that changed the carboxy-terminus to a sequence that resembles ( $40 \%$ identity) the $\mathrm{Ca}_{V} 1.1$ channel found in skeletal muscle (Kotturi and Jefferies, 2005). The second splice variant, $\mathrm{Ca}_{V} 1.4 \mathrm{~b}$, lacks exons 32 and 36 causing a deletion of the extracellular loop between S3 and S4 in motif IV. CaV1.4b also has an early stop codon that prematurely truncates the channel. The voltage sensing motif is not spliced out; however, it has been proposed that removal of the extracellular loop may alter the voltage sensing function of this channel (Kotturi and Jefferies, 2005). Upon membrane depolarization, the S4 voltage sensor domain moves and this splicing event may leave the domain in a conformation that prevents S4 movement (Bezanilla, 2002; Jurkat-Rott and Lehmann-Horn, 2004). Since their discovery in T cells (Kotturi and Jefferies, 2005), alternative splice variants of other Cav channels have been found. Analogous structural changes have been 
subsequently noted for Cav 1.1 (Matza and Flavell, 2009) with one isoform similarly lacking the extracellular loop between S3 and S4 in motif IV that translated to shifted voltage sensitivity in muscle cells (Tuluc et al., 2009). These structural changes likely explain the insensitivity of T cell Cav 1 channels to be activated by cell depolarization and instead, gating in $\mathrm{T}$ cells may be through alternate mechanisms such as ER store-depletion or TCR signaling. Supporting this hypothesis, Jha et al. (2009) recently found $\mathrm{Ca}_{V} 1.4$ to be localized to lipid rafts in the plasma membrane of murine $\mathrm{T}$ cells. Cav 1.4 was found to be associated with components of the $\mathrm{T}$ cell signaling complex. Given its location, $\mathrm{Cav}_{\mathrm{V}} 1$ channel activity could be regulated in $\mathrm{T}$ cells by downstream TCR signaling events.

Recent in vivo studies have directly addressed the controversy regarding the importance of voltage-dependent $\mathrm{Ca}^{2+}$ channels in $\mathrm{T}$ cell function. Mice with targeted deletions in the regulatory $\beta$ subunits that mediate $\mathrm{Ca}_{\mathrm{V}}$ channel assembly, plasma membrane targeting, and activation have been described (Badou et al., 2006; Buraei and Yang, 2010). The $\beta 3$ and $\beta 4$ family members are expressed in naïve $\mathrm{CD} 4^{+} \mathrm{T}$ cells and upregulated in activated $\mathrm{T}$ cells. Upon TCR cross-linking, $\mathrm{CD} 4^{+} \mathrm{T}$ cells from $\beta 3$ or $\beta 4$-deficient mice showed impaired $\mathrm{Ca}^{2+}$ influx, NFAT nuclear translocation, and cytokine secretion (Badou et al., 2006). Cav1.1 expression was found to be reduced in the $\beta 4$-deficient $\mathrm{T}$ cells providing a possible role for Cav1 in lymphocyte function (Badou et al., 2006). The same group later examined $\mathrm{CD}^{+} \mathrm{T}$ cell populations in a $\beta 3$-deficient mouse (Jha et al., 2009). $\beta 3^{-1-}$ mice have reduced numbers of $\mathrm{CD}^{+} \mathrm{T}$ cells possibly due to increased spontaneous apoptosis induced by higher expression of Fas. Upon activation, these $\mathrm{CD} 8^{+} \mathrm{T}$ cells have decreased $\mathrm{Ca}^{2+}$ entry, proliferation, and NFAT nuclear translocation. $\beta 3$ was found to associate with $\mathrm{Ca}_{\mathrm{V}} 1.4$ and several TCR signaling proteins suggesting its role in TCR gated $\mathrm{Ca}^{2+}$ signaling (Jha et al., 2009). Similarly, when the AHNAK1 protein, a large scaffold protein required for Cav 1.1 surface expression, was disrupted, $\mathrm{T}$ cells had reduced $\mathrm{Ca}^{2+}$ influx and NFAT activation that equated to poor effector function (Matza et al., 2008, 2009). Recently, Cabral et al. (2010) began to address differential $\mathrm{Ca}^{2+}$ signaling in $\mathrm{T}$ cell subsets. This study demonstrated that $\mathrm{Ca}_{V} 1.2$ and $\mathrm{Ca}_{V} 1.3$ channels were expressed in Th2 but not Th1 differentiated effector T cells. Knockdown of Cav1.2 and/or Cav1.3 expression in Th2 cells with antisense oligodeoxynucleotides resulted in reduced $\mathrm{Ca}^{2+}$ influx following TCR stimulation and impaired cytokine secretion (Cabral et al., 2010). In addition, Th2 cells with disrupted Cav 1 expression were impaired in their ability to induce asthma in an adoptive transfer model (Cabral et al., 2010). Further studies defining the Cav1 channel subtype or splice variant essential to various stages of development and activation of the $\mathrm{T}$ cell subsets will likely provide an explanation for differences in $\mathrm{Ca}^{2+}$ responses.

Omilusik et al. (2011) used a murine model deficient for $\mathrm{Ca}_{V} 1.4$ (Mansergh et al., 2005), one of the pore-forming subunits of a $\mathrm{Ca}_{V}$ channel, to unequivocally establish a $\mathrm{T}$ cell-intrinsic role for $\mathrm{Cav}_{\mathrm{v}} 1 \mathrm{~s}$ in the activation, survival, and maintenance of naïve $\mathrm{CD}^{+}$and $\mathrm{CD}^{+} \mathrm{T}$ cells in vivo. Cav1.4 was shown to be essential for TCRinduced regulation of cytosolic free $\mathrm{Ca}^{2+}$ and downstream TCR signaling, impacting activation of the Ras/ERK and NFAT pathways, IL-7 receptor expression and IL-7 responsiveness. The loss of
Cav 1.4 and subsequently naïve peripheral $\mathrm{T}$ cells resulted in deficient immune responses when challenged with the model bacteria, L. monocytogenes. Instead of being activated by $\mathrm{Ca}^{2+}$ store release as in the case of ORAI1, it appears that Cav1.4 may operate to create intracellular $\mathrm{Ca}^{2+}$ stores in the ER. Low-level TCR signaling through interactions with self-antigens (i.e., self-peptides/selfMHC molecules) may result in $\mathrm{Ca}_{v} 1.4$-mediated $\mathrm{Ca}^{2+}$ influx from outside the cell, allowing the filling of intracellular stores and the initiation of a pro-survival program. This recent data supports the concept that in the absence of Cav1.4, there is a reduction in the influx of extracellular $\mathrm{Ca}^{2+}$ coupled to self/MHC-TCR interaction, resulting in low cytoplasmic $\mathrm{Ca}^{2+}$ levels and depleted $\mathrm{Ca}^{2+}$ ER stores (Omilusik et al., 2011). Therefore, when Cav 1.4-deficient $\mathrm{T}$ cells are stimulated through the TCR, there is a defective $\mathrm{Ca}^{2+}$ release from the ER as a result of lower levels of stored $\mathrm{Ca}^{2+}$, decreased subsequent SOCE, and diminished inward $\mathrm{Ca}^{2+}$ flux through CRAC channels leading to weakened $\mathrm{Ca}^{2+}$-dependent signaling. Overall, the absence of tonic survival signals provided by $\mathrm{Ca}_{V} 1.4$ results in failure of naïve $\mathrm{T}$ cells to thrive and perpetuates a state of immunological activation and exhaustion (Omilusik et al., 2011). Studies on other immune cells support this contention. For example, Cav 1.2 expressed in mast cells has been reported to protect against antigen-induced cell death by maintaining mitochondria integrity and inhibiting the mitochondrial cell death pathway (Suzuki et al., 2009). Using pharmacological agents and siRNA specific knockdown, Suzuki et al. (2009) demonstrated that $\mathrm{Ca}_{V} 1.2$ channels protect mast cells from undergoing apoptosis following FceRI activation as discerned by assessing mitochondrial membrane potential, cytochrome $c$ release, and caspase-3/7 activation. Furthermore, though it remains unclear, it appears that $\mathrm{Ca}^{2+}$ influx through Cav1.2 at the plasma membrane may be important for maintenance of the mitochondrial $\mathrm{Ca}^{2+}$ concentration, thereby providing the cell with pro-survival signals (Suzuki et al., 2009). In conclusion, it is of importance to note that knockouts of the components of $\mathrm{Cav}_{\mathrm{v}} 1$ channels in $\mathrm{T}$ cells have, by large, more severe phenotypes than those of other categories of $\mathrm{Ca}^{2+}$ channels in $\mathrm{T}$ cells and, certainly, this argues strongly that $\mathrm{Cav}_{\mathrm{V}} 1$ channels play a significant role in regulating and orchestrating $\mathrm{T}$ cell biology.

It is interesting to consider and likely profoundly important for integrating the multiple functions of $\mathrm{T}$ cells with other homeostatic processes, that Cav 1 coexist in excitable and non-excitable cells with other $\mathrm{Ca}^{2+}$ channels and the interplay between the channels all likely contribute to the highly regulated $\mathrm{Ca}^{2+}$ signaling system. Cav1 channels have been shown to interact with the ER/sarcoplasmic reticulum (SR) ryanodine receptors (RyRs) in excitable cells (Lanner et al., 2010). In skeletal muscle, Cav 1.1 channels are activated by membrane depolarization and through a physical interaction with RyR1 stimulate the release of $\mathrm{Ca}^{2+}$ from the SR. Similarly, in cardiac muscle, $\mathrm{Ca}_{V} 1.2$ is triggered to mediate entry of extracellular $\mathrm{Ca}^{2+}$ which in turn activates RyR2 channels to release intracellular $\mathrm{Ca}^{2+}$ stores (Lanner et al., 2010). Both mechanisms have also been observed in neurons (Chavis et al., 1996; Mouton et al., 2001). Although T cells express RyRs (Hosoi et al., 2001) and these receptors have been shown to contribute to $\mathrm{Ca}^{2+}$ signaling following TCR activation (Hohenegger et al., 1999; 
Schwarzmann et al., 2002; Conrad et al., 2004), further studies are needed to demonstrate a Cav 1-RyR interaction.

An interplay between voltage-gated sodium channels (VGSC) and $\mathrm{Ca}_{1} 1$ has also been suggested to shape the $\mathrm{T}$ cell $\mathrm{Ca}^{2+}$ signal. In excitable cells such as muscle and neurons, membrane depolarization by VGSC leads to an increase in cytosolic $\mathrm{Ca}^{2+}$ through the activation of $\mathrm{Cav}_{\mathrm{V}}$ channels (Dravid et al., 2004; Fekete et al., 2009; Catterall, 2010). A recent study in T cells has determined an essential role for a VGSC in positive selection (Lo et al., 2012). Pharmacological inhibition and shRNA-mediated knockdown was used to demonstrate that the VGSC composed of a pore-forming SCN5a and a regulatory SCN5b subunit is necessary for $\mathrm{Ca}^{2+}$ influx during positive selection of $\mathrm{CD} 4^{+} \mathrm{T}$ cells. It is proposed that this SCN5a-SCN5b channel is expressed in double positive $\mathrm{T}$ cells in order to convert a weak positive selection signal into a sustained $\mathrm{Ca}^{2+}$ flux necessary for positive selection to take place. However, once in the periphery, $\mathrm{T}$ cells no longer express the channel to eliminate the possibility of autoimmunity (Lo et al., 2012). ORAI1 and STIM1 do not seem to contribute to thymic development of conventional TCR $\alpha \beta$ T cells (Oh-Hora et al., 2013); therefore, it is an interesting idea that VGSC activation by kinases downstream of the TCR (Rook et al., 2012) can induce $\mathrm{Ca}^{2+}$ signaling by $\mathrm{Ca} v 1$ in developing $\mathrm{T}$ cells. Further studies are required to formally demonstrate a functional link between Cav 1 and VGSC channels in lymphocytes.

Recently, an interesting reciprocal relationship between $\mathrm{Ca}_{v} 1.2$ and ORAI1 has been described (Park et al., 2010; Wang et al., 2010). After $\mathrm{Ca}^{2+}$ store depletion in the ER, STIM1 oligomers form at ER-plasma membrane junctions allowing the STIM1 CRAC-activating domain (CAD) to interact with the C-terminus of ORAI1 and $\mathrm{Ca}_{V} 1.2$ channels. ORAIl channels are activated by STIM1 and subsequently open causing sustained $\mathrm{Ca}^{2+}$ influx from the extracellular space. Conversely, STIM1 inhibits $\mathrm{Ca}^{2+}$ influx through $\mathrm{Ca}_{V} 1.2$ and promotes its internalization, further shutting down the activity of the channel (Park et al., 2010;

\section{REFERENCES}

Adriouch, S., Dox, C., Welge, V., Seman, M., Koch-Nolte, F., and Haag, F. (2002). Cutting edge: a natural P451L mutation in the cytoplasmic domain impairs the function of the mouse P2X7 receptor. J. Immunol. 169, 4108-4112.

Affaticati, P., Mignen, O., Jambou, F., Potier, M. C., Klingel-Schmitt, I., Degrouard, J., et al. (2011). Sustained calcium signalling and caspase- 3 activation involve NMDA receptors in thymocytes in contact with dendritic cells. Cell Death Differ. 18, 99-108. doi:10.1038/ cdd.2010.79

Badou, A., Jha, M. K., Matza, D., Mehal, W. Z., Freichel, M., Flockerzi, V., et al. (2006). Critical role for the beta regulatory subunits of Cav channels in $\mathrm{T}$ lymphocyte function. Proc. Natl. Acad. Sci. U.S.A. 103, 15529-15534. doi:10.1073/ pnas. 0607262103
Baricordi, O. R., Ferrari, D., Melchiorri, L., Chiozzi, P., Hanau, S., Chiari, E., et al. (1996). An ATP-activated channel is involved in mitogenic stimulation of human T lymphocytes. Blood $87,682-690$.

Berridge, M. J. (1993). Inositol trisphosphate and calcium signalling. Nature 361, 315-325. doi:10.1038/ $361315 \mathrm{a} 0$

Bezanilla, F. (2002). Voltage sensor movements. J. Gen. Physiol. 120, 465-473. doi:10.1085/jgp.20028660

Birx, D. L., Berger, M., and Fleisher, T. A. (1984). The interference of $\mathrm{T}$ cell activation by calcium channel blocking agents. J. Immunol. 133, 2904-2909.

Bodding, M., Wissenbach, U., and Flockerzi, V. (2002). The recombinant human TRPV6 channel functions as $\mathrm{Ca} 2+$ sensor in human embryonic kidney and rat basophilic leukemia cells. J. Biol. Chem. 277, 36656-36664. doi:10.1074/jbc.M202822200

Wang et al., 2010). It is interesting to speculate that strong TCR signaling through engagement by a foreign peptide-MHC may trigger this activation of ORAI1 and inhibition of $\mathrm{Ca}_{\mathrm{V}} 1$ channels (Figure 1). However, low-level TCR signaling through interactions with self-antigens (i.e., self-peptides/self-MHC molecules) may not induce STIM1 to localize to the plasma membrane thereby activating $\mathrm{Cav}_{\mathrm{V}}$ and co-ordinately inhibiting ORAI1. This results in Cav1-mediated $\mathrm{Ca}^{2+}$ influx from outside the cell, filling of depleted intracellular stores, and induction of a signaling cascade to activate a pro-survival program within the naïve $\mathrm{T}$ cell. The activation and inhibition of $\mathrm{Ca}_{V} 1$ channels through STIM1 or other TCR-mediated events is an intriguing concept and will likely be the focus of many new studies.

Although $\mathrm{Ca}_{v} 1$ function is vital for $\mathrm{T}$ cell $\mathrm{Ca}^{2+}$ signaling, their specific functions have yet to be fully explored. Further work is required to clarify the role played by each Cav 1 channel family member as well as the other $\mathrm{Ca}^{2+}$ channels in shaping the $\mathrm{Ca}^{2+}$ signal. Altogether, these studies do provide a new framework for understanding the regulation of lymphocyte biology through the function of several $\mathrm{Ca}^{2+}$ channels, particularly the L-type $\mathrm{Ca}^{2+}$ channels, in the storage of intracellular $\mathrm{Ca}^{2+}$ and operative $\mathrm{Ca}^{2+}$ regulation during antigen receptor-mediated signal transduction.

Overall, the translational aspects of the current research in the field of $\mathrm{Ca}^{2+}$ channel biology have direct implications in designing new modalities for modifying $\mathrm{T}$ cell responses using drugs that are known to control $\mathrm{Ca}^{2+}$ channels activities, such as the plethora of drugs that already exist for modifying Cav 1 channels. Agents that target the $\mathrm{Ca}_{V} 1$ splice variants expressed in lymphocytes and inhibit the activity of the channel may serve as more specific immunosuppressants than the current options. Relevant applications for these agents may include therapy for autoimmune diseases, reduction of transplant rejection risk, and treatment of other disorders requiring suppression or in the case of existing immunodeficiency, activation of the immune system.

Boldyrev, A. A., Bryushkova, E. A., and Vladychenskaya, E. A. (2012). NMDA receptors in immune competent cells. Biochemistry Mosc. 77, 128-134. doi:10.1134/S0006297912020022

Boldyrev, A. A., Kazey, V. I., Leinsoo, T. A., Mashkina, A. P., Tyulina, O. V., Johnson, P., et al. (2004). Rodent lymphocytes express functionally active glutamate receptors. Biochem. Biophys. Res. Commun. 324, 133-139. doi:10.1016/j.bbrc.2004.09.019

Bours, M. J., Swennen, E. L., Di Virgilio, F., Cronstein, B. N., and Dagnelie, P. C. (2006). Adenosine 5 '-triphosphate and adenosine as endogenous signaling molecules in immunity and inflammation. Pharmacol. Ther. 112, 358-404.

Brandman, O., Liou, J., Park, W. S., and Meyer, T. (2007). STIM2 is a feedback regulator that stabilizes basal cytosolic and endoplasmic reticulum $\mathrm{Ca} 2+$ levels. Cell 131, 1327-1339. doi:10.1016/j.cell.2007.11.039

Buraei, Z., and Yang, J. (2010). The ss subunit of voltage-gated $\mathrm{Ca} 2+$ channels. Physiol. Rev. 90, 1461-1506. doi:10.1152/physrev.00057.2009

Cabral, M. D., Paulet, P. E., Robert, V., Gomes, B., Renoud, M. L., Savignac, M., et al. (2010). Knocking down Cav1 calcium channels implicated in Th2 cell activation prevents experimental asthma. Am. J. Respir. Crit. Care Med. 181, 1310-1317. doi:10.1164/rccm. 200907-1166OC

Catterall, W. A. (2010). Signaling complexes of voltage-gated sodium and calcium channels. Neurosci. Lett. 486, 107-116. doi:10.1016/j.neulet.2010.08.085

Chavis, P., Fagni, L., Lansman, J. B., and Bockaert, J. (1996). Functional coupling between ryanodine receptors and L-type calcium channels in neurons. Nature 382, 719-722. doi:10.1038/382719a0 
Clapham, D. E., Montell, C., Schultz, G., and Julius, D. (2003). International Union of Pharmacology. XLIII. Compendium of voltage-gated ion channels: transient receptor potential channels. Pharmacol. Rev. 55, 591-596. doi:10.1124/pr.55.4.6

Colucci, A., Giunti, R., Senesi, S., Bygrave, F. L., Benedetti, A., and Gamberucci, A. (2009). Effect of nifedipine on capacitive calcium entry in Jurkat $\mathrm{T}$ lymphocytes. Arch. Biochem. Biophys. 481, 80-85. doi:10.1016/j.abb.2008.10.002

Conrad, D. M., Hanniman, E. A., Watson, C. L., Mader, J. S., and Hoskin, D. W. (2004). Ryanodine receptor signaling is required for anti-CD3-induced $\mathrm{T}$ cell proliferation, interleukin-2 synthesis, and interleukin-2 receptor signaling. J. Cell. Biochem. 92, 387-399. doi:10.1002/jcb.20064

Cui, J., Bian, J. S., Kagan, A., and McDonald, T. V. (2002). CaT1 contributes to the storesoperated calcium current in Jurkat T-lymphocytes. J. Biol. Chem. 277, 47175-47183. doi:10.1074/jbc.M205870200

Cullen, P. J., and Lockyer, P. J. (2002). Integration of calcium and Ras signalling. Nat. Rev. Mol. Cell Biol. 3, 339-348. doi:10.1038/ nrm808

de Weille, J. R., Schweitz, H., Maes, P., Tartar, A., and Lazdunski, M. (1991). Calciseptine, a peptide isolated from black mamba venom, is a specific blocker of the Ltype calcium channel. Proc. Natl. Acad. Sci. U.S.A. 88, 2437-2440. doi:10.1073/pnas.88.6.2437

DeHaven, W. I., Smyth, J. T., Boyles, R. R., and Putney, J. W. Jr. (2007). Calcium inhibition and calcium potentiation of Orail, Orai2, and Orai3 calcium releaseactivated calcium channels. J. Biol. Chem. 282, 17548-17556. doi:10.1074/jbc.M611374200

Densmore, J. J., Haverstick, D. M., Szabo, G., and Gray, L. S. (1996). A voltage-operable current is involved in $\mathrm{Ca} 2+$ entry in human lymphocytes whereas ICRAC has no apparent role. Am. J. Physiol. 271, C1494C1503.

Densmore, J. J., Szabo, G., and Gray, L. S. (1992). A voltage-gated calcium channel is linked to the antigen receptor in Jurkat $\mathrm{T}$ lymphocytes. FEBS Lett. 312, 161-164. doi:10.1016/0014-5793(92)80926-8

Dravid, S. M., Baden, D. G., and Murray, T. F. (2004). Brevetoxin activation of voltage-gated sodium channels regulates $\mathrm{Ca}$ dynamics and
ERK1/2 phosphorylation in murine neocortical neurons. J. Neurochem. 89, 739-749. doi:10.1111/j.14714159.2004.02407.x

Dupuis, G., Aoudjit, F., Ricard, I., and Payet, M. D. (1993). Effects of modulators of cytosolic $\mathrm{Ca} 2+$ on phytohemagglutin-dependent $\mathrm{Ca} 2+$ response and interleukin-2 production in Jurkat cells. J. Leukoc. Biol. 53, 66-72.

Fanger, C. M., Hoth, M., Crabtree, G. R., and Lewis, R. S. (1995). Characterization of $\mathrm{T}$ cell mutants with defects in capacitative calcium entry: genetic evidence for the physiological roles of CRAC channels. J. Cell Biol. 131, 655-667. doi:10.1083/jcb.131.3.655

Fanger, C. M., Neben, A. L., and Cahalan, M. D. (2000). Differential Ca2+ influx, $\mathrm{KCa}$ channel activity, and $\mathrm{Ca} 2+$ clearance distinguish $\mathrm{Th} 1$ and Th2 lymphocytes. J. Immunol. 164, 1153-1160.

Fekete, A., Franklin, L., Ikemoto, T., Rozsa, B., Lendvai, B., Sylvester Vizi, E., et al. (2009). Mechanism of the persistent sodium current activator veratridineevoked $\mathrm{Ca}$ elevation: implication for epilepsy. J. Neurochem. 111, 745-756. doi:10.1111/j.14714159.2009.06368.x

Feske, S. (2009). ORAI1 and STIM1 deficiency in human and mice: roles of store-operated $\mathrm{Ca} 2+$ entry in the immune system and beyond. Immunol. Rev. 231, 189-209. doi:10.1111/j.1600065X.2009.00818.x

Feske, S., Giltnane, J., Dolmetsch, R., Staudt, L. M., and Rao, A. (2001). Gene regulation mediated by calcium signals in $\mathrm{T}$ lymphocytes. Nat. Immunol. 2, 316-324. doi: $10.1038 / 86318$

Feske, S., Gwack, Y., Prakriya, M., Srikanth, S., Puppel, S. H., Tanasa, B., et al. (2006). A mutation in Orail causes immune deficiency by abrogating CRAC channel function. Nature 441, 179-185. doi:10.1038/nature04702

Feske, S., Prakriya, M., Rao, A., and Lewis, R. S. (2005). A severe defect in CRAC $\mathrm{Ca} 2+$ channel activation and altered $\mathrm{K}+$ channel gating in $\mathrm{T}$ cells from immunodeficient patients. J. Exp. Med. 202, 651-662. doi:10.1084/jem.20050687

Feske, S., Skolnik, E. Y., and Prakriya, M. (2012). Ion channels and transporters in lymphocyte function and immunity. Nat. Rev. Immunol. 12, 532-547. doi:10.1038/nri3233

Filippini, A., Taffs, R. E., and Sitkovsky, M. V. (1990). Extracellular ATP in
T-lymphocyte activation: possible role in effector functions. Proc. Natl. Acad. Sci. U.S.A. 87, 8267-8271. doi:10.1073/pnas.87.21.8267

Fisher, S. E., Ciccodicola, A., Tanaka, K., Curci, A., Desicato, S., D'urso, M., et al. (1997). Sequence-based exon prediction around the synaptophysin locus reveals a gene-rich area containing novel genes in human proximal Xp. Genomics 45, 340-347. doi:10.1006/geno.1997.4941

Gasser, A., Glassmeier, G., Fliegert, R., Langhorst, M. F., Meinke, S. Hein, D., et al. (2006). Activation of $\mathrm{T}$ cell calcium influx by the second messenger ADP-ribose. J. Biol. Chem. 281, 2489-2496. doi:10.1074/jbc.M506525200

Gelfand, E. W., Cheung, R. K., Grinstein, S., and Mills, G. B. (1986) Characterization of the role for calcium influx in mitogen-induced triggering of human $\mathrm{T}$ cells. Identification of calcium-dependent and calcium-independent signals. Eur. J. Immunol. 16, 907-912. doi:10.1002/eji.1830160806

Gomes, B., Savignac, M., Moreau, M., Leclerc, C., Lory, P., Guery, J. C. et al. (2004). Lymphocyte calcium signaling involves dihydropyridinesensitive L-type calcium channels: facts and controversies. Crit. Rev. Immunol. 24, 425-447. doi:10.1615/ CritRevImmunol.v24.i6.30

Grafton, G., and Thwaite, L. (2001). Calcium channels in lymphocytes. Immunology 104, 119-126. doi:10.1046/j.00192805.2001.01321.x

Gwack, Y., Srikanth, S., Oh-Hora, M., Hogan, P. G., Lamperti, E. D. Yamashita, M., et al. (2008). Hair loss and defective $\mathrm{T}$ - and $\mathrm{B}$-cell function in mice lacking ORAI1. Mol. Cell. Biol. 28, 5209-5222. doi:10.1128/MCB.00360-08

Hara, Y., Wakamori, M., Ishii, M., Maeno, E., Nishida, M., Yoshida T., et al. (2002). LTRPC2 Ca2+permeable channel activated by changes in redox status confers susceptibility to cell death. Mol. Cell 9, 163-173. doi:10.1016/S10972765(01)00438-5

He, L. P., Hewavitharana, T., Soboloff, J., Spassova, M. A., and Gill, D. L. (2005). A functional link between store-operated and TRPC channels revealed by the 3,5-bis-trifluoromethylpyrazole derivative, BTP2. J. Biol. Chem. 280, 10997-11006. doi:10.1074/jbc.M411797200

Hofmann, T., Obukhov, A. G., Schaefer, M., Harteneck, C., Gudermann, T., and Schultz, G. (1999).
Direct activation of human TRPC6 and TRPC3 channels by diacylglycerol. Nature 397, 259-263. doi:10.1038/16711

Hogan, P. G., Chen, L., Nardone, J., and Rao, A. (2003). Transcriptional regulation by calcium, calcineurin, and NFAT. Genes Dev. 17, 2205-2232.

Hogan, P. G., Lewis, R. S., and Rao, A. (2010). Molecular basis of calcium signaling in lymphocytes: STIM and ORAI. Annu. Rev. Immunol. 28, 491-533. doi:10.1146/ annurev.immunol.021908.132550

Hohenegger, M., Berg, I., Weigl, L., Mayr, G. W., Potter, B. V., and Guse, A. H. (1999). Pharmacological activation of the ryanodine receptor in Jurkat T-lymphocytes. Br. J. Pharmacol. 128, 1235-1240. doi:10.1038/sj.bjp.0702935

Hosoi, E., Nishizaki, C., Gallagher, K. L. Wyre, H. W., Matsuo, Y., and Sei, Y. (2001). Expression of the ryanodine receptor isoforms in immune cells. $J$. Immunol. 167, 4887-4894.

Jha, M. K., Badou, A., Meissner, M., McRory, J. E., Freichel, M., Flockerzi, V., et al. (2009). Defective survival of naive $\mathrm{CD} 8+\mathrm{T}$ lymphocytes in the absence of the beta3 regulatory subunit of voltage-gated calcium channels. Nat. Immunol. 10, 1275-1282. doi:10.1038/ni.1793

Junger, W. G. (2011). Immune cell regulation by autocrine purinergic signalling. Nat. Rev. Immunol. 11, 201-212. doi:10.1038/nri2938

Jurkat-Rott, K., and Lehmann-Horn, F. (2004). The impact of splice isoforms on voltage-gated calcium channel alphal subunits. J. Physiol. (Lond.) 554, 609-619. doi:10.1113/jphysiol.2003.052712

Khan, A. A., Steiner, J. P., Klein, M. G., Schneider, M. F., and Snyder, S. H. (1992). IP3 receptor: localization to plasma membrane of $\mathrm{T}$ cells and cocapping with the $\mathrm{T}$ cell receptor. Science 257, 815-818. doi:10.1126/science.1323146

Kotturi, M. F., Carlow, D. A., Lee, J. C., Ziltener, H. J., and Jefferies, W. A. (2003). Identification and functional characterization of voltage-dependent calcium channels in $\mathrm{T}$ lymphocytes. J. Biol. Chem. 278, 46949-46960. doi:10.1074/jbc.M309268200

Kotturi, M. F., Hunt, S. V., and Jefferies, W. A. (2006). Roles of CRAC and Cav-like channels in T cells: more than one gatekeeper? Trends Pharmacol. Sci. 27, 360-367. doi:10.1016/j.tips.2006.05.007

Kotturi, M. F., and Jefferies, W. A. (2005). Molecular characterization of L-type calcium 
channel splice variants expressed in human $\mathrm{T}$ lymphocytes. Mol. Immunol. 42, 1461-1474. doi:10.1016/j.molimm.2005.01.014

Lacinova, L. (2005). Voltage-dependent calcium channels. Gen. Physiol. Biophys. 24(Suppl. 1), 1-78.

Lanner, J. T., Georgiou, D. K., Joshi, A. D., and Hamilton, S. L. (2010). Ryanodine receptors: structure, expression, molecular details, and function in calcium release. Cold Spring Harb. Perspect. Biol. 2, a003996. doi:10.1101/cshperspect.a003996

Le Deist, F., Hivroz, C., Partiseti, M., Thomas, C., Buc, H. A., Oleastro, M., et al. (1995). A primary T-cell immunodeficiency associated with defective transmembrane calcium influx. Blood 85, 1053-1062.

Lee, L. F., Lih, C. J., Huang, C. J., Cao, T., Cohen, S. N., and McDevitt, H. O. (2008). Genomic expression profiling of TNF-alpha-treated BDC2.5 diabetogenic CD4+ T cells. Proc. Natl. Acad. Sci. U.S.A. 105, 10107-10112. doi:10.1073/pnas.0803336105

Liou, J., Fivaz, M., Inoue, T., and Meyer, T. (2007). Live-cell imaging reveals sequential oligomerization and local plasma membrane targeting of stromal interaction molecule 1 after $\mathrm{Ca} 2+$ store depletion. Proc. Natl. Acad. Sci. U.S.A. 104, 9301-9306. doi:10.1073/pnas.0702866104

Liou, J., Kim, M. L., Heo, W. D., Jones, J. T., Myers, J. W., Ferrell, J. E. Jr., et al. (2005). STIM is a $\mathrm{Ca} 2+$ sensor essential for $\mathrm{Ca} 2+-$ store-depletion-triggered $\mathrm{Ca} 2+$ influx. Curr. Biol. 15, 1235-1241. doi:10.1016/j.cub.2005.05.055

Lis, A., Peinelt, C., Beck, A., Parvez, S., Monteilh-Zoller, M., Fleig, A., et al. (2007). CRACM1, CRACM2, and CRACM3 are store-operated $\mathrm{Ca} 2+$ channels with distinct functional properties. Curr. Biol. 17, 794-800. doi:10.1016/j.cub.2007.03.065

Lo, W. L., Donermeyer, D. L., and Allen, P. M. (2012). A voltagegated sodium channel is essential for the positive selection of $\mathrm{CD} 4(+)$ T cells. Nat. Immunol. 13, 880-887. doi:10.1038/ni.2379

Lombardi, G., Dianzani, C., Miglio, G., Canonico, P. L., and Fantozzi, R. (2001). Characterization of ionotropic glutamate receptors in human lymphocytes. Br. J. Pharmacol. 133, 936-944. doi:10.1038/sj.bjp.0704134

Luik, R. M., Wu, M. M., Buchanan, J., and Lewis, R. S. (2006). The elementary unit of store-operated Ca2+ entry: local activation of CRAC channels by STIM1 at ER-plasma membrane junctions. J. Cell Biol. 174, 815-825. doi:10.1083/jcb.200604015

Macian, F. (2005). NFAT proteins: key regulators of $\mathrm{T}$-cell development and function. Nat. Rev. Immunol. 5, 472-484. doi:10.1038/nri1632

Mansergh, F., Orton, N. C., Vessey, J. P., Lalonde, M. R., Stell, W. K., Tremblay, F., et al. (2005). Mutation of the calcium channel gene Cacnalf disrupts calcium signaling, synaptic transmission and cellular organization in mouse retina. Hum. Mol. Genet. 14, 3035-3046. doi:10.1093/hmg/ddi336

Marx, M., Weber, M., Merkel, F., Meyer Zum Buschenfelde, K. H., and Kohler, H. (1990). Additive effects of calcium antagonists on cyclosporin A-induced inhibition of T-cell proliferation. Nephrol. Dial. Transplant. 5, 1038-1044. doi:10.1093/ndt/5.12.1038

Mashkina, A. P., Cizkova, D., Vanicky, I., and Boldyrev, A. A. (2010). NMDA receptors are expressed in lymphocytes activated both in vitro and in vivo. Cell. Mol. Neurobiol. 30, 901-907. doi:10.1007/s10571010-9519-7

Mashkina, A. P., Tyulina, O. V., Solovyova, T. I., Kovalenko, E. I., Kanevski, L. M., Johnson, P., et al. (2007). The excitotoxic effect of NMDA on human lymphocyte immune function. Neurochem. Int. 51, 356-360. doi:10.1016/j.neuint.2007.04.009

Massullo, P., Sumoza-Toledo, A., Bhagat, H., and Partida-Sanchez, S. (2006). TRPM channels, calcium and redox sensors during innate immune responses. Semin. Cell Dev. Biol. 17, 654-666. doi:10.1016/j.semcdb.2006.11.006

Matza, D., Badou, A., Jha, M. K., Willinger, T., Antov, A., Sanjabi, S., et al. (2009). Requirement for AHNAK1mediated calcium signaling during T lymphocyte cytolysis. Proc. Natl. Acad. Sci. U.S.A. 106, 9785-9790. doi:10.1073/pnas.0902844106

Matza, D., Badou, A., Kobayashi, K. S., Goldsmith-Pestana, K., Masuda, Y., Komuro, A., et al. (2008). A scaffold protein, AHNAK1, is required for calcium signaling during $\mathrm{T}$ cell activation. Immunity 28, 64-74. doi:10.1016/j.immuni.2007.11.020

Matza, D., and Flavell, R. A. (2009). Roles of $\mathrm{Ca}(\mathrm{v})$ channels and AHNAK1 in T cells: the beauty and the beast. Immunol. Rev. 231, 257-264. doi:10.1111/j.1600065X.2009.00805.X

McRory, J. E., Hamid, J., Doering, C. J., Garcia, E., Parker, R., Hamming, K., et al. (2004). The CACNAIF gene encodes an L-type calcium channel with unique biophysical properties and tissue distribution. $\mathrm{J}$. Neurosci. 24, 1707-1718. doi:10.1523/ JNEUROSCI.4846-03.2004

Melzer, N., Hicking, G., Gobel, K., and Wiendl, H. (2012). TRPM2 cation channels modulate $\mathrm{T}$ cell effector functions and contribute to autoimmune CNS inflammation. PLOS ONE 7:e47617. doi:10.1371/journal.pone.0047617

Miglio, G., Dianzani, C., Fallarini, S., Fantozzi, R., and Lombardi, G. (2007). Stimulation of N-methylD-aspartate receptors modulates Jurkat $\mathrm{T}$ cell growth and adhesion to fibronectin. Biochem. Biophys. Res. Commun. 361, 404-409. doi:10.1016/j.bbrc.2007.07.015

Miglio, G., Varsaldi, F., and Lombardi, G. (2005). Human T lymphocytes express $\mathrm{N}$-methyl-D-aspartate receptors functionally active in controlling $\mathrm{T}$ cell activation. Biochem. Biophys. Res. Commun. 338, 1875-1883. doi:10.1016/j.bbrc.2005.10.164

Mignen, O., Thompson, J. L., and Shuttleworth, T. J. (2007). STIM1 regulates Ca2+ entry via arachidonate-regulated $\mathrm{Ca} 2+-$ selective (ARC) channels without store depletion or translocation to the plasma membrane. J. Physiol. (Lond.) 579, 703-715. doi:10.1113/jphysiol.2006.122432

Mignen, O., Thompson, J. L., and Shuttleworth, T. J. (2009). The molecular architecture of the arachidonateregulated $\mathrm{Ca} 2+$-selective ARC channel is a pentameric assembly of Orail and Orai3 subunits. $J$. Physiol. (Lond.) 587, 4181-4197. doi:10.1113/jphysiol.2009.174193

Montell, C., and Rubin, G. M. (1989). Molecular characterization of the Drosophila trp locus: a putative integral membrane protein required for phototransduction. Neuron 2, 1313-1323. doi:10.1016/0896-6273(89)90069-X

Mouton, J., Marty, I., Villaz, M., Feltz, A., and Maulet, Y. (2001). Molecular interaction of dihydropyridine receptors with type-1 ryanodine receptors in rat brain. Biochem. J. 354, 597-603. doi:10.1042/02646021:3540597

Oh-Hora, M. (2009). Calcium signaling in the development and function of T-lineage cells. Immunol. Rev. 231, 210-224. doi:10.1111/j.1600065X.2009.00819.x

Oh-Hora, M., Komatsu, N., Pishyareh, M., Feske, S., Hori, S., Taniguchi, M., et al. (2013). Agonistselected $\mathrm{T}$ cell development requires strong $\mathrm{T}$ cell receptor signaling and store-operated calcium entry. Immunity 38, 881-895. doi:10.1016/ j.immuni.2013.02.008

Oh-Hora, M., Yamashita, M., Hogan, P. G., Sharma, S., Lamperti, E., Chung, W., et al. (2008). Dual functions for the endoplasmic reticulum calcium sensors STIM1 and STIM2 in T cell activation and tolerance. Nat. Immunol. 9, 432-443. doi:10.1038/ni1574

Omilusik, K., Priatel, J. J., Chen, X. Wang, Y. T., Xu, H., Choi, K. B., et al. (2011). The CaV1.4 calcium channel is a critical regulator of $\mathrm{T}$ cell receptor signaling and naive $\mathrm{T}$ cell homeostasis. Immunity 35, 349-360. doi:10.1016/j.immuni.2011.07.011

Owsianik, G., Talavera, K., Voets, T., and Nilius, B. (2006). Permeation and selectivity of TRP channels. Annu. Rev. Physiol. 68, 685-717. doi:10.1146/ annurev.physiol.68.040204.101406

Padberg, W. M., Bodewig, C., Schafer, H., Muhrer, K. H., and Schwemmle, K. (1990). Synergistic immunosuppressive effect of low-dose cyclosporine $\mathrm{A}$ and the calcium antagonist nifedipine, mediated by the generation of suppressor cells. Transplant. Proc. 22, 2337.

Park, C. Y., Hoover, P. J., Mullins, F. M., Bachhawat, P., Covington, E. D., Raunser, S., et al. (2009). STIM1 clusters and activates CRAC channels via direct binding of a cytosolic domain to Orail. Cell 136, 876-890. doi:10.1016/j.cell.2009.02.014

Park, C. Y., Shcheglovitov, A., and Dolmetsch, R. (2010). The CRAC channel activator STIM1 binds and inhibits L-type voltage-gated calcium channels. Science 330, 101-105. doi:10.1126/science.1191027

Partiseti, M., Le Deist, F., Hivroz, C., Fischer, A., Korn, H., and Choquet, D. (1994). The calcium current activated by $\mathrm{T}$ cell receptor and store depletion in human lymphocytes is absent in a primary immunodeficiency. J. Biol. Chem. 269, 32327-32335.

Patterson, R. L., Boehning, D., and Snyder, S. H. (2004). Inositol 1,4,5-trisphosphate receptors as signal integrators. Аnnu. Rev. Biochem. 73, 437-465. doi:10.1146/ annurev.biochem.73.071403.161303

Penna, A., Demuro, A., Yeromin, A. V., Zhang, S. L., Safrina, O., Parker, I., et al. (2008). The CRAC channel consists of a tetramer formed by Stim-induced dimerization of Orai dimers. Nature 456, 116-120. doi:10.1038/nature07338 
Perraud, A. L., Fleig, A., Dunn, C. A., Bagley, L. A., Launay, P., Schmitz, C., et al. (2001). ADP-ribose gating of the calcium-permeable LTRPC2 channel revealed by Nudix motif homology. Nature 411, 595-599. doi:10.1038/35079100

Philipp, S., Strauss, B., Hirnet, D., Wissenbach, U., Mery, L., Flockerzi, V., et al. (2003). TRPC3 mediates T-cell receptor-dependent calcium entry in human T-lymphocytes. J. Biol. Chem. 278, 26629-26638. doi:10.1074/jbc.M304044200

Picard, C., McCarl, C. A., Papolos, A., Khalil, S., Luthy, K., Hivroz, C., et al. (2009). STIM1 mutation associated with a syndrome of immunodeficiency and autoimmunity. N. Engl. J. Med. 360, 1971-1980. doi:10.1056/NEJMoa0900082

Robert, V., Triffaux, E., Savignac, M., and Pelletier, L. (2011). Calcium signalling in T-lymphocytes. Biochimie 93, 2087-2094. doi:10.1016/j.biochi.2011.06.016

Rook, M. B., Evers, M. M., Vos, M. A., and Bierhuizen, M. F. (2012). Biology of cardiac sodium channel Nav1.5 expression. Cardiovasc. Res. 93, 12-23. doi:10.1093/cvr/cvr252

Roos, J., Digregorio, P. J., Yeromin, A. V., Ohlsen, K., Lioudyno, M., Zhang, S., et al. (2005). STIM1, an essential and conserved component of store-operated $\mathrm{Ca} 2+$ channel function. J. Cell Biol. 169, 435-445. doi:10.1083/jcb.200502019

Sadighi Akha, A. A., Willmott, N. J., Brickley, K., Dolphin, A. C., Galione, A., and Hunt, S. V. (1996). Anti-Ig-induced calcium influx in rat B lymphocytes mediated by cGMP through a dihydropyridine-sensitive channel. J. Biol. Chem. 271, 7297-7300. doi:10.1074/jbc.271.13.7297

Schenk, U., Frascoli, M., Proietti, M., Geffers, R., Traggiai, E., Buer, J., et al. (2011). ATP inhibits the generation and function of regulatory $\mathrm{T}$ cells through the activation of purinergic P2X receptors. Sci. Signal. 4, ra12. doi:10.1126/scisignal.2001270

Schenk, U., Westendorf, A. M., Radaelli, E., Casati, A., Ferro, M., Fumagalli, M., et al. (2008). Purinergic control of $\mathrm{T}$ cell activation by ATP released through pannexin-1 hemichannels. Sci. Signal. 1, ra6. doi:10.1126/scisignal.1160583

Schuhmann, M. K., Stegner, D., BernaErro, A., Bittner, S., Braun, A., Kleinschnitz, C., et al. (2010). Stromal interaction molecules 1 and 2 are key regulators of autoreactive $\mathrm{T}$ cell activation in murine autoimmune central nervous system inflammation. J. Immunol. 184, 1536-1542. doi:10.4049/jimmunol.0902161

Schwarz, E. C., Wissenbach, U., Niemeyer, B. A., Strauss, B., Philipp, S. E., Flockerzi, V., et al. (2006). TRPV6 potentiates calcium-dependent cell proliferation. Cell Calcium 39, 163-173. doi:10.1016/j.ceca.2005.10.006

Schwarz, E. C., Wolfs, M. J., Tonner, S., Wenning, A. S., Quintana, A., Griesemer, D., et al. (2007). TRP channels in lymphocytes. Handb. Exp. Pharmacol. 179, 445-456. doi:10.1007/978-3540-34891-7_26

Schwarzmann, N., Kunerth, S., Weber, K., Mayr, G. W., and Guse, A. H. (2002). Knock-down of the type 3 ryanodine receptor impairs sustained $\mathrm{Ca} 2+$ signaling via the $\mathrm{T}$ cell receptor/CD3 complex. J. Biol. Chem. 277, 50636-50642. doi:10.1074/jbc.M209061200

Smith-Garvin, J. E., Koretzky, G. A., and Jordan, M. S. (2009). $\mathrm{T}$ cell activation. Annu. Rev. Immunol. 27, 591-619. doi:10.1146/ annurev.immunol.021908.132706

Soboloff, J., Spassova, M. A., Hewavitharana, T., He, L. P., Xu, W., Johnstone, L. S., et al. (2006). STIM2 is an inhibitor of STIM1mediated store-operated $\mathrm{Ca} 2+$ Entry. Curr. Biol. 16, 1465-1470. doi:10.1016/j.cub.2006.05.051

Solle, M., Labasi, J., Perregaux, D. G., Stam, E., Petrushova, N., Koller, B. H., et al. (2001). Altered cytokine production in mice lacking $\mathrm{P} 2 \mathrm{X}(7)$ receptors. J. Biol. Chem. 276, 125-132. doi:10.1074/jbc.M006781200

Srikanth, S., and Gwack, Y. (2012). Orail, STIM1, and their associating partners. J. Physiol. (Lond.) 590, 4169-4177. doi:10.1113/jphysiol.2012.231522

Stathopulos, P. B., Zheng, L., and Ikura, M. (2009). Stromal interaction molecule (STIM) 1 and STIM2 calcium sensing regions exhibit distinct unfolding and oligomerization kinetics. J. Biol. Chem. 284, 728-732. doi:10.1074/jbc.C800178200

Stokes, L., Gordon, J., and Grafton, G. (2004). Non-voltage-gated Ltype $\mathrm{Ca} 2+$ channels in human $\mathrm{T}$ cells: pharmacology and molecular characterization of the major alpha pore-forming and auxiliary beta-subunits. J. Biol. Chem. 279, 19566-19573. doi:10.1074/jbc.M401481200

Strom, T. M., Nyakatura, G., ApfelstedtSylla, E., Hellebrand, H., Lorenz, B., Weber, B. H., et al. (1998). An L-type calcium-channel gene mutated in incomplete X-linked congenital stationary night blindness. Nat. Genet. 19, 260-263. doi:10.1038/940

Suzuki, Y., Yoshimaru, T., Inoue, T., and Ra, C. (2009). Ca(v)1.2 L-type Ca2+ channel protects mast cells against activation-induced cell death by preventing mitochondrial integrity disruption. Mol. Immunol. 46, 2370-2380. doi:10.1016/j.molimm. 2009.03.017

Tanimura, A., Tojyo, Y., and Turner, R. J. (2000). Evidence that type I, II, and III inositol 1,4,5-trisphosphate receptors can occur as integral plasma membrane proteins. J. Biol. Chem. 275, 27488-27493.

Teixeiro, E., and Daniels, M. A. (2010). ERK and cell death: ERK location and $\mathrm{T}$ cell selection. FEBS J. 277, 30-38. doi:10.1111/j.17424658.2009.07368.x

Tone, Y., Furuuchi, K., Kojima, Y., Tykocinski, M. L., Greene, M. I., and Tone, M. (2008). Smad3 and NFAT cooperate to induce Foxp3 expression through its enhancer. Nat. Immunol. 9, 194-202. doi:10.1038/ni1549

Tuluc, P., Molenda, N., Schlick, B., Obermair, G. J., Flucher, B. E., and Jurkat-Rott, K. (2009). A $\mathrm{CaV} 1.1 \mathrm{Ca} 2+$ channel splice variant with high conductance and voltage-sensitivity alters EC coupling in developing skeletal muscle. Biophys. J. 96, 35-44. doi:10.1016/j.bpj.2008.09.027

Vazquez, G., Lievremont, J. P., St, J. B. G., and Putney, J. W. Jr. (2001). Human Trp3 forms both inositol trisphosphate receptor-dependent and receptor-independent storeoperated cation channels in DT40 avian B lymphocytes. Proc. Natl. Acad. Sci. U.S.A. 98, 11777-11782. doi:10.1073/pnas.201238198

Vig, M., Dehaven, W. I., Bird, G. S., Billingsley, J. M., Wang, H., Rao, P. E., et al. (2008). Defective mast cell effector functions in mice lacking the CRACM1 pore subunit of storeoperated calcium release-activated calcium channels. Nat. Immunol. 9 , 89-96. doi:10.1038/nrg2314

Vig, M., Peinelt, C., Beck, A., Koomoa, D. L., Rabah, D., Koblan-Huberson, M., et al. (2006). CRACM1 is a plasma membrane protein essential for store-operated $\mathrm{Ca} 2+$ entry. Science 312, 1220-1223. doi:10.1126/science. 1127883

Voets, T., Prenen, J., Fleig, A., Vennekens, R., Watanabe, H., Hoenderop, J. G., et al. (2001). CaT1 and the calcium release-activated calcium channel manifest distinct pore properties. J. Biol. Chem. 276, 47767-47770.

Vyas, J. M., Van Der Veen, A. G., and Ploegh, H. L. (2008). The known unknowns of antigen processing and presentation. Nat. Rev. Immunol. 8, 607-618. doi:10.1038/nri2368

Wang, Y., Deng, X., Mancarella, S., Hendron, E., Eguchi, S., Soboloff, J., et al. (2010). The calcium store sensor, STIM1, reciprocally controls Orai and CaV1.2 channels. Science 330, 105-109. doi:10.1126/science.1191086

Weber, K. S., Miller, M. J., and Allen, P. M. (2008). Th17 cells exhibit a distinct calcium profile from Th1 and Th2 cells and have Th1-like motility and NF-AT nuclear localization. J. Immunol. 180, 1442-1450.

Wenning, A. S., Neblung, K., Strauss, B., Wolfs, M. J., Sappok, A., Hoth, M., et al. (2011). TRP expression pattern and the functional importance of TRPC3 in primary human T-cells. Biochim. Biophys. Acta 1813, 412-423. doi:10.1016/j.bbamcr.2010.12.022

Williams, R. T., Manji, S. S., Parker, N. J., Hancock, M. S., Van Stekelenburg, L., Eid, J. P., et al. (2001). Identification and characterization of the STIM (stromal interaction molecule) gene family: coding for a novel class of transmembrane proteins. Biochem. J. 357, 673-685. doi:10.1042/0264-6021:3570673

Woehrle, T., Yip, L., Elkhal, A., Sumi, Y., Chen, Y., Yao, Y., et al. (2010). Pannexin-1 hemichannel-mediated ATP release together with P2X1 and $\mathrm{P} 2 \mathrm{X} 4$ receptors regulate T-cell activation at the immune synapse. Blood 116, 3475-3484. doi:10.1182/blood2010-04-277707

Wu, M. M., Buchanan, J., Luik, R. M., and Lewis, R. S. (2006a). Ca2+ store depletion causes STIM1 to accumulate in ER regions closely associated with the plasma membrane. J. Cell Biol. 174, 803-813. doi:10.1083/jcb.200604014

Wu, Y., Borde, M., Heissmeyer, V., Feuerer, M., Lapan, A. D., Stroud, J. C., et al. (2006b). FOXP3 controls regulatory $\mathrm{T}$ cell function through cooperation with NFAT. Cell 126, 375-387. doi:10.1016/j.cell.2006.05.042

Wulff, H., Beeton, C., and Chandy, K. G. (2003). Potassium channels as therapeutic targets for autoimmune disorders. Curr. Opin. Drug Discov. Devel. 6, 640-647.

Wulff, H., Knaus, H. G., Pennington, M., and Chandy, K. G. (2004). $\mathrm{K}+$ channel expression during $\mathrm{B}$ cell differentiation: implications for 
immunomodulation and autoimmunity. J. Immunol. 173, 776-786.

Xu, P., Lu, J., Li, Z., Yu, X., Chen, L., and $\mathrm{Xu}, \mathrm{T}$. (2006). Aggregation of STIM1 underneath the plasma membrane induces clustering of Orail. Biochem. Biophys. Res. Commun. 350, 969-976. doi:10.1016/j.bbrc.2006.09.134

Yip, L., Woehrle, T., Corriden, R., Hirsh, M., Chen, Y., Inoue, Y., et al. (2009). Autocrine regulation of T-cell activation by ATP release and P2X7 receptors. FASEB J. 23, 1685-1693. doi:10.1096/fj.08-126458

Zainullina, L. F., Yamidanov, R. S., Vakhitov, V. A., and Vakhitova, Y. V. (2011). NMDA receptors as a possible component of store-operated $\mathrm{Ca}(2)(+)$ entry in human T-lymphocytes. Biochemistry Mosc. 76, 1220-1226. doi:10.1134/S0006297911110034

Zhang, S. L., Yeromin, A. V., Zhang, X. H., Yu, Y., Safrina, O., Penna, A., et al. (2006). Genome-wide RNAi screen of $\mathrm{Ca}(2+)$ influx identifies genes that regulate $\mathrm{Ca}(2+)$ releaseactivated $\mathrm{Ca}(2+)$ channel activity. Proc. Natl. Acad. Sci. U.S.A. 103, 9357-9362. doi:10.1073/pnas.06031 61103

Zitt, C., Strauss, B., Schwarz, E. C., Spaeth, N., Rast, G., Hatzelmann, A., et al. (2004). Potent inhibition of $\mathrm{Ca} 2+$ release-activated $\mathrm{Ca} 2+$ channels and T-lymphocyte activation by the pyrazole derivative BTP2. J. Biol. Chem. 279, 12427-12437. doi:10.1074/jbc.M309297200
Zweifach, A., and Lewis, R. S (1993). Mitogen-regulated Ca2+ current of $\mathrm{T}$ lymphocytes is activated by depletion of intracellular $\mathrm{Ca} 2+$ stores. Proc. Natl. Acad. Sci. U.S.A. 90, 6295-6299. doi:10.1073/pnas.90.13.6295

Conflict of Interest Statement: The authors declare that the research was conducted in the absence of any commercial or financial relationships that could be construed as a potential conflict of interest.

Received: 01 February 2013; accepted: 11 June 2013; published online: 24 June 2013.
Citation: Omilusik KD, Nohara $L L$, Stanwood S and Jefferies WA (2013) Weft, warp, and weave: the intricate tapestry of calcium channels regulating T lymphocyte function. Front. Immunol. 4:164. doi: 10.3389/fimmu.2013.00164

This article was submitted to Frontiers in $T$ Cell Biology, a specialty of Frontiers in Immunology.

Copyright (C) 2013 Omilusik, Nohara, Stanwood and Jefferies. This is an open-access article distributed under the terms of the Creative Commons Attribution License, which permits use, distribution and reproduction in other forums, provided the original authors and source are credited and subject to any copyright notices concerning any third-party graphics etc. 